SAND93 -7049

Unlimited Release

UC -274

\title{
Silicon Concentrator Solar Cell Research
}

M. A. Green, J. Zhao, A. Wang, X. Dai,

A. Milne, S. Cai, A. Aberle, S. R. Wenham

Centre for Photovoltaic Devices and Systems

University of New South Wales

Kensington, Australia, 2033

Prepared by Sandia National Laboratories Albuquerque, New Mexico 87185 and Livermore, California 94550 for the United States Department of Energy under Contract DE-AC04-76DP00789

Printed June 1993 
Issued by Sandia National Laboratories, operated for the United States Department of Energy by Sandia Corporation.

NOTICE: This report was prepared as an account of work sponsored by an agency of the United States Government. Neither the United States Government nor any agency thereof, nor any of their employees, nor any of their contractors, subcontractors, or their employees, makes any warranty, express or implied, or assumes any legal liability or responsibility for the accuracy, completeness, or usefulness of any information, apparatus, product, or process disclosed, or represents that its use would not infringe privately owned rights. Reference herein to any specific commercial product, process, or service by trade name, trademark, manufacturer, or otherwise, does not necessarily constitute or imply its endorsement, recommendation, or favoring by the United States Government, any agency thereof or any of their contractors or subcontractors. The views and opinions expressed herein do not necessarily state or reflect those of the United States Government, any agency thereof or any of their contractors.

Printed in the United States of America. This report has been reproduced directly from the best available copy.

Available to DOE and DOE contractors from

Office of Scientific and Technical Information

PO Box 62

Oak Ridge, TN 37831

Prices available from (615) 576-8401, FTS 626-8401

Available to the public from

National Technical Information Service

US Department of Commerce

5285 Port Royal Rd

Springfield, VA 22161

NTIS price codes

Printed copy: A03

Microfiche copy: A01 


\title{
SILICON CONCENTRATOR SOLAR CELL RESEARCH
}

\author{
M.A. Green, J. Zhao, A. Wang, X. Dal, A. Milne \\ S. Cal, A. Aberle, S.R. Wenham \\ Centre for Photovoltaic Devices and Systems \\ University of New South Wales \\ Kensington, Australia 2033
}

Sandia Contract 27-1167

\begin{abstract}
This report describes work conducted between December 1990 and May 1992 continuing research on silicon concentrator solar cells. The objectives of the work were to improve the performance of high-efficiency cells upon p-type substrates, to investigate the ultraviolet stability of such cells, to develop concentrator cells based on n-type substrates, and to transfer technology to appropriate commercial environments. Key results include the identification of contact resistance between boron-defused areas and rear aluminum as the source of anomalously large series resistance in both $\mathrm{p}$ - and n-type cells. A major achievement of the present project was the successful transfer of cell technology to both Applied Solar Energy Corporation and Solarex Corporation.
\end{abstract}




\section{ACKNOWLEDGEMENTS}

The authors would like to thank other members of the Centre for Photovoltaic Devices and Systems who have contributed to this project. The contributions of Operations Manager, Mark Silver, and his support team are particularly acknowledged. Also gratefully acknowledged are the contributions of staff at Sandia National Laboratories, particularly Sandia Technical Monitor, Paul Basore. The Centre for Photovoltaic Devices and Systems is supported by the Australian Research Council's Special Research Scheme and by Pacific Power. 


\section{DISCLAIMER}

Portions of this document may be illegible electronic image products. Images are produced from the best available original document. 


\section{TABLE OF CONTENTS}

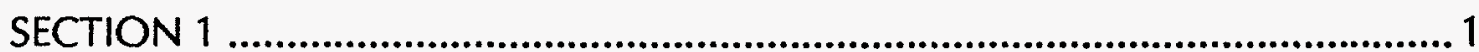

1. SUMMARY 1

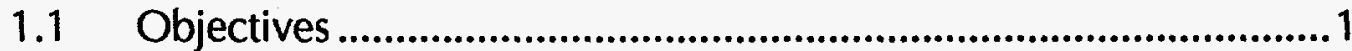

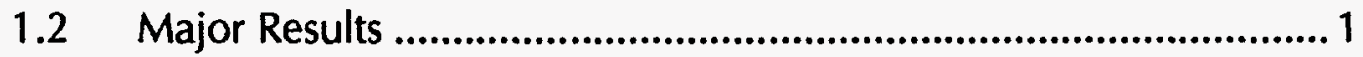

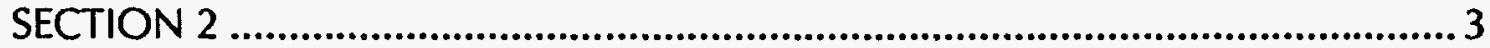

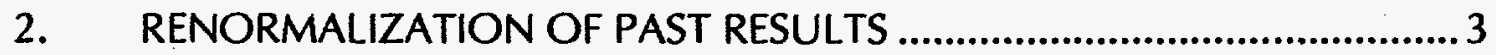

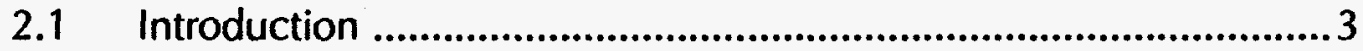

2.2 Laser Grooved Cell...................................................................... 3

2.3 Passivated Emitter Solar Cell ....................................................... 4

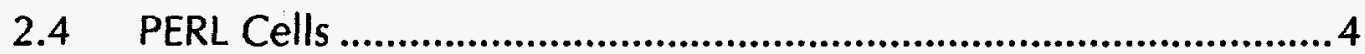

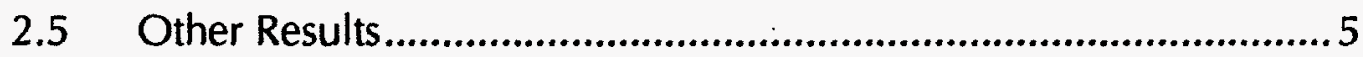

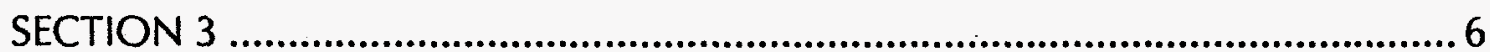

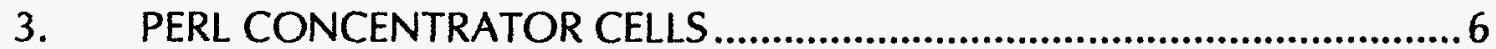

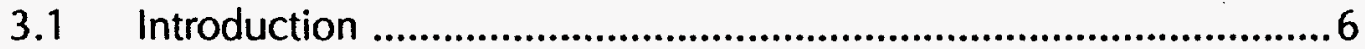

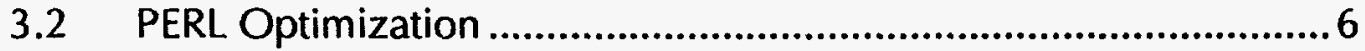

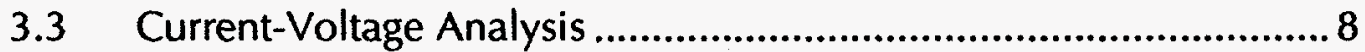

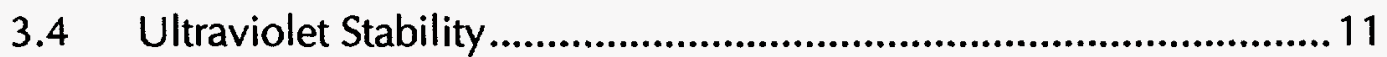

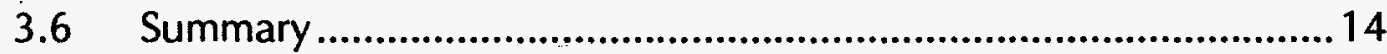

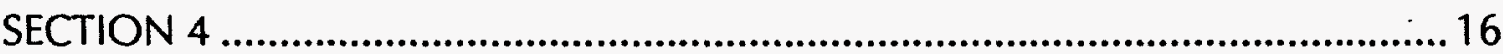

4. N-TYPE PASSIVATED EMITTER CELLS ............................................... 16

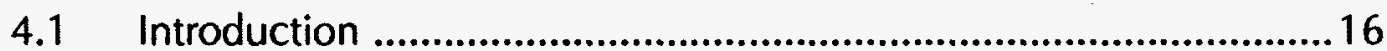

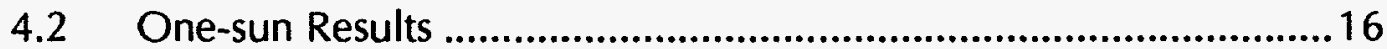

$4.3 \quad$ N-Type Concentrator Cells ........................................................ 18

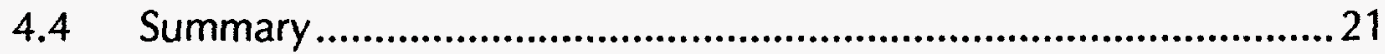

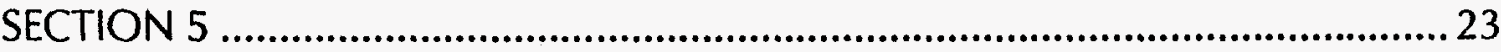

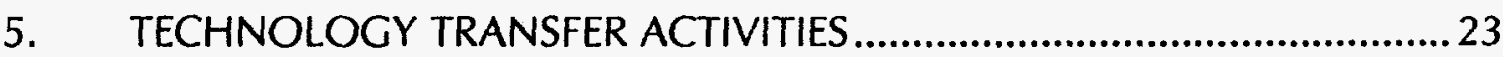

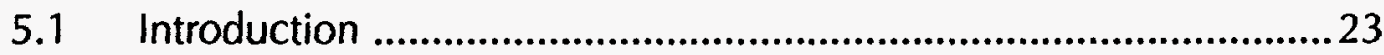

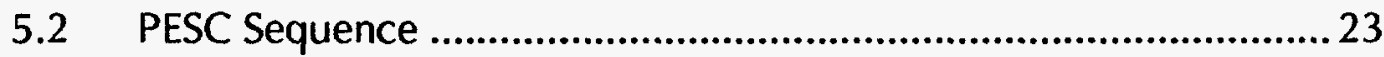

5.3 Buried Contact Cell Sequence ...................................................24

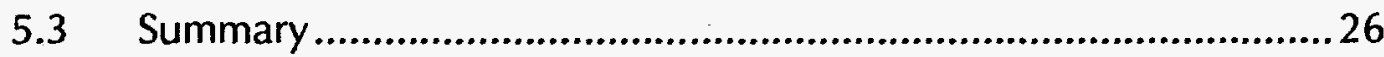

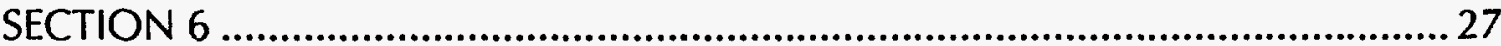

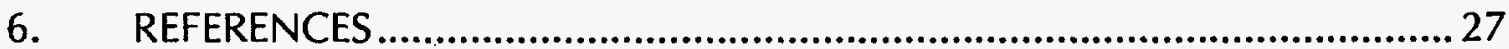




\section{SECTION 1}

\section{SUMMARY}

\subsection{Objectives}

The broad objective of this project conducted between December 1990 and May 1992 was to develop a concentrator cell technology that employs cost-effective processing procedures and provides the high performance required to achieve costeffective power generation in the U.S. utility market. Specific activities directed toward achieving this broad objective involved the optimization of PERL (passivated emitter, rear locally-diffused) concentrator cells to demonstrate cells with stable efficiency above $26 \%$ at concentration levels above 200 suns, working with Sandia in establishing the ultra-violet (UV) stability of these cells, the development of PERT (passivated emitter, rear totally-diffused) cells and the development of concentrator cells upon n-type substrates. Another important component of the project was technology transfer to commercial environments in the U.S. and the provision of cells for prototype concentrator modules.

\subsection{Major Results}

A change in calibration standards at Sandia National Laboratories during the course of the project has shifted cell efficiency measurements to values more conservative than in the past by approximately $4.8 \%$. All performance measurements reported will be relative to these new standards, implemented in January 1991. Relevant to these new standards, the efficiency target of $26 \%$ converts to an efficiency of $24.8 \%$. Cells of this efficiency have been demonstrated, but at concentration levels much lower than the 200 suns that formed the project objective.

One of the most important results of the project was the elimination of UV stability as an immediate issue for these cells. Although cells are affected by the high energy UV light from a mercury lamp source, the timescales of the resulting degradation appear too long to be of major concern in terrestrial applications, particularly when the UV filtering action of lenses is taken into account. 
Further work remains before PERL concentrator cell technology is developed to its full potential. Recent studies suggest that the high carrier densities resulting from operation under concentrated light are very favorable for minimizing surface recombination velocity in these devices. However, the cells have excessive resistance which is attributed to contact resistance between the rear contact metal and boron doped regions of the cell. Further work should allow this effect to be eliminated and the targets of the present project to be surpassed in the medium term.

Excellent progress was made in the development of both PERL and PERT cells upon n-type substrates. Due to the high recombination contributions of boron diffused regions, best results were obtained when boron diffusion was restricted to planar rather than textured cell surfaces. This stimulated the development of "front surface field" or "rear junction" cells for n-type substrates. Concentrator cells implemented in this configuration showed excellent one-sun response. However, performance under concentration was disappointing due to marked sublinearity in device responsivity with increasing illumination level. This sublinearity is described by an earlier theory developed by our group, but came as a disappointing surprise in the present work. One conclusion from the present work is that the best PERL concentrator cell structure would incorporate low resistivity p-type substrates.

Since work remained to demonstrate cells of the target performance level, it was premature to consider supplying cells for prototype modules. However, excellent progress was obtained with technology transfer during the course of the project. As a result of technology transfer activities, the PESC cell (passivated emitter solar cell) technology, developed for concentrator applications in earlier Sandia-supported work, has now been successfully implemented at Applied Solar Energy Corporation (ASEC). Concentrator cells of substantially improved efficiency approaching $22 \%$ have now been fabricated by ASEC. The company has also released data sheets documenting the availability of a new line of high efficiency cells for space application, using this technology. Technology transfer to Solarex Corporation also occurred near the end of the present project. 


\section{SECTION 2}

\section{RENORMALIZATION OF PAST RESULTS}

\subsection{Introduction}

To document the impact of the change in calibration standards at Sandia National Laboratories during the course of the present project, this section describes the renormalization of past UNSW concentrator cell results to the new calibration values. Under the new calibration, efficiency up to $24.8 \%$ has been demonstrated by UNSW cells of $1.6-\mathrm{cm}^{2}$ area and efficiency up to $21.5 \%$ for $20-\mathrm{cm}^{2}$ large-area cells.

\subsection{Laser Grooved Cell}

Excellent results for large area cells have been obtained using the laser-grooved approach originally developed for low-cost non-concentrating cells. Table 2.1 shows the best results obtained to date upon concentrator cells with this technology.

Table 2.1: Efficiency of a large-area concentrator cell (no prismatic cover) fabricated with advanced laser processing. Cell area is $20.0-\mathrm{cm}^{2}$ and responsivity is 0.379 A/W (Direct AM1.5 spectrum, $25^{\circ} \mathrm{C}$, measurements courtesy of Sandia National Laboratories, corrected to January 1991 calibration).

\begin{tabular}{|l|c|c|c|}
\hline Suns & $V_{\text {oc }}(\mathrm{mV})$ & FF (\%) & Effic. (\%) \\
\hline 1 & 644 & 81.3 & 19.9 \\
\hline 5.4 & 686 & 81.7 & 21.2 \\
\hline 10.7 & 703 & 80.9 & 21.5 \\
\hline 21.0 & 719 & 77.7 & 21.2 \\
\hline 46.2 & 737 & 73.9 & 20.6 \\
\hline
\end{tabular}

As can be seen from this table, efficiency above $21 \%$ has been demonstrated in the 5-25 suns range, referenced to the new Sandia calibration. These cells did not employ ENTECH prismatic covers, but did employ a special double-grooving step reported in more detail elsewhere [1]. 


\subsection{Passivated Emitter Solar Cell}

Although now surpassed by PERL cells in terms of efficiencies at low concentration levels, the earlier PESC cells developed by our group [2] remain the most reliable for obtaining high efficiency at high concentrations. Table 2.2 shows the best result demonstrated with this technology when referenced to the new calibration. The peak efficiency demonstrated is $24 \%$ at $100-150$ suns' concentration.

Table 2.2: Measured performance of cell W471-2 as a function of concentration level after application of prismatic covers. Measured at Sandia National Laboratories under the direct beam AM1.5 spectrum and corrected to January1991 calibration (ASTM E-891 at $25^{\circ} \mathrm{C}$ ). Responsivity of the cell is $0.373 \mathrm{AW}$.

\begin{tabular}{|l|c|c|c|}
\hline Suns & $V_{\text {oc }}(\mathrm{mV})$ & $\mathrm{FF}(\%)$ & Effic. (\%) \\
\hline 1 & 666 & 81.3 & 20.2 \\
\hline 21 & 743 & 83.8 & 23.2 \\
\hline 107 & 780 & 82.3 & 24.0 \\
\hline 213 & 792 & 79.8 & 23.6 \\
\hline 261 & 796 & 78.1 & 23.2 \\
\hline
\end{tabular}

\subsection{PERL Cells}

Under the new calibration, the highest efficiency demonstrated [1] for a PERL cell is $24.8 \%$ as shown in Table 2.3 .

Table 2.3: Efficiency of cell Z255-1 under concentrated sunlight after application of

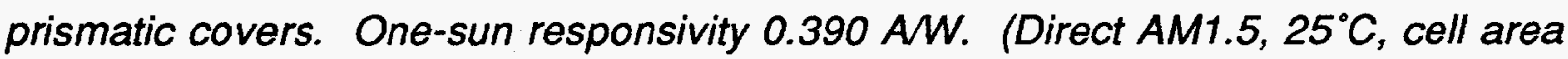
$1.56-\mathrm{cm}^{2}$, measurements courtesy of Sandia National Laboratories, corrected to January1991 calibration).

\begin{tabular}{|l|c|c|c|}
\hline Suns & $V_{\text {oc }}(\mathrm{mV})$ & FF (\%) & Effic. (\%) \\
\hline 1 & 690 & 82.7 & 22.3 \\
\hline 21 & 762 & 83.1 & 24.8 \\
\hline 152 & 802 & 63.0 & 19.7 \\
\hline
\end{tabular}


As apparent from this table, peak efficiency is obtained at relatively low concentration levels. Some PERL cells have performed quite creditably at high concentration levels. Table 2.4 shows the best result demonstrated to date by a PERL cell at above 150 suns' concentration [1]. Efficiency close to $23 \%$ has been demonstrated at such levels.

Table 2.4: Efficiency of cell Z252-1 under concentrated sunlight after application of prismatic covers. One-sun responsivity $0.381 \mathrm{AW}$. (Direct $A M 1.5$ spectrum, $25^{\circ} \mathrm{C}$, cell area 1.56- $\mathrm{cm}^{2}$, measurements courtesy of Sandia National Laboratories, corrected to January 1991 calibration).

\begin{tabular}{|l|c|c|c|}
\hline Suns & $V_{o c}(\mathrm{mV})$ & $F F(\%)$ & Effic. (\%) \\
\hline 1 & 683 & 79.4 & 20.7 \\
\hline 32 & 772 & 82.9 & 24.4 \\
\hline 158 & 804 & 73.5 & 22.6 \\
\hline
\end{tabular}

\subsection{Other Results}

Other significant concentrator cell results obtained by other groups are also affected by this recalibration. For example, the $27.8 \%$ efficiency measured for a Stanford point contact cell [3] would become $26.4 \%$, the $29.2 \%$ measured for a Varian gallium arsenide cell [4] would become $27.8 \%$, and the $34.2 \%$ measured for a Boeing tandem cell [5] would become $32.6 \%$. 


\section{SECTION 3}

\section{PERL CONCENTRATOR CELLS}

\subsection{Introduction}

Although PERL cells have demonstrated reasonable performance under concentration as documented in Tables 2.3 and 2.4, their potential at high concentration levels, at the start of the project, was still largely untapped. This was due to higher resistance in the cells than expected. One aim of the present project was to increase PERL cell performance at the high concentration levels by increased understanding of such limiting factors. A second aim was to investigate the ultraviolet (UV) stability of the cells, given the strong sensitivity of high-efficiency silicon cells developed at Stanford University to such radiation [6].

\subsection{PERL Optimization}

Figure 3.1 shows the PERL cell structure, while the basic processing sequence for producing concentrator cells of this type is outlined in Table 3.1 [1].

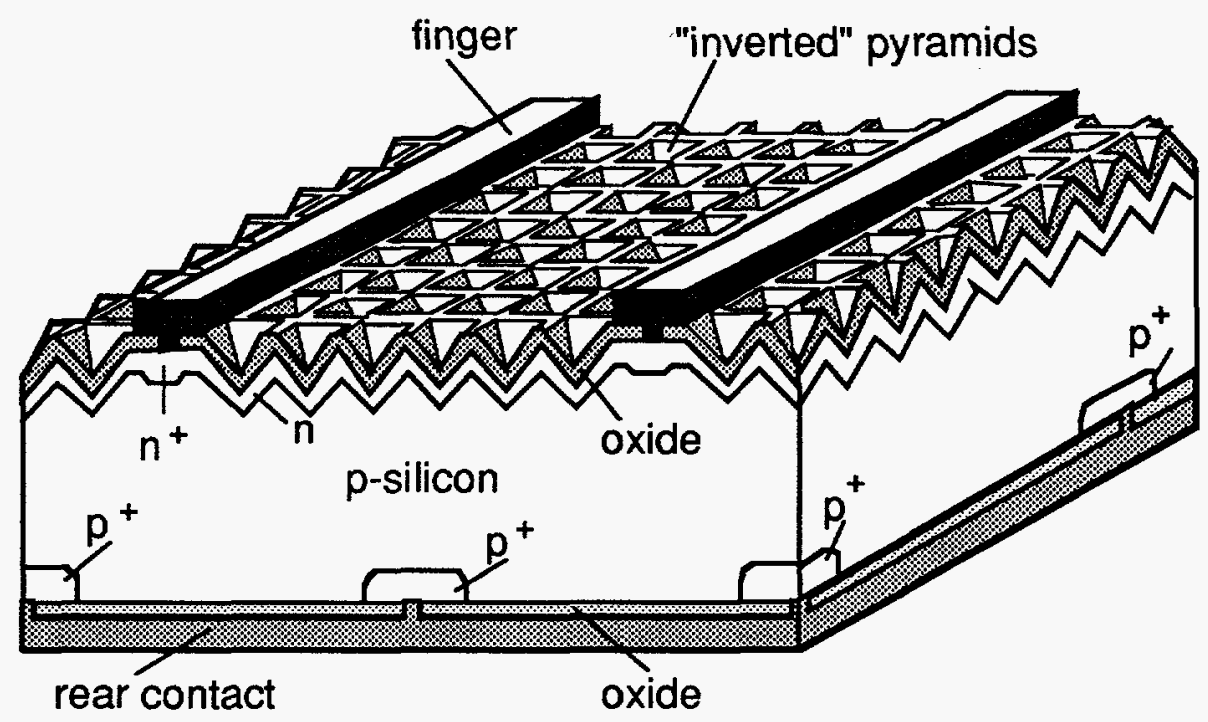

Figure 3.1: PERL cell (passivated emitter, rear locally diffused cell). 
Table 3.1: Processing Sequence for PERL Concentrator Cells (Z252-1 fabricated on $0.2-\Omega-\mathrm{cm}$ substrate, $Z 255-1$ on $0.5-\Omega-\mathrm{cm}$, both cells used $10 \times 10-\mu \mathrm{m}$ rear contact holes on $250 \mu \mathrm{m}$ spacing)

\section{STEP}

1. Wafer Selection

2. Oxide Growth

3. Oxide Patterning

4. Surface Etching

5. Rounding

6. Oxide Removal

7. Rounding

8. Oxide Growth

9. Oxide Patterning

10. Boron Diffusion

11. Deglaze

12. Oxide Growth

13. Oxide Patterning

14. Heavy $\mathrm{N}+$ Diffusion

15. Deglaze

16. Oxide Growth

17. Oxide Patterning

18. Light $\mathrm{N}^{+}$Diffusion

19. Deglaze

20. Passivation Oxide Growth

21. Oxide Patterning

22. Photoresist Patterning

23. Top Contact Metal

24. Rear Contact Metal

25. Ag Plating Top

26. Sinter

\section{PARAMETERS}

0.2-0.5 $\Omega-\mathrm{cm},(100), F Z$, p-type. Boron doped, 280- $\mu \mathrm{m}$ thick, $\Phi=50.8-\mathrm{mm}$. Both sides polished $1000^{\circ} \mathrm{C}, 1.5 \mathrm{hr}, 2 \% \mathrm{TCA}$ in $\mathrm{O}_{2}$ Inverted pyramids, active area $\mathrm{KOH}: \mathrm{H}_{2} \mathrm{O}=8 \mathrm{~g} / 100 \mathrm{ml} ., 70^{\circ} \mathrm{C}$. $\mathrm{NH}_{4} \mathrm{~F}: \mathrm{HNO}_{3}=1: 30,1 \mathrm{~min}$. $\mathrm{HF}: \mathrm{H}_{2} \mathrm{O}=1: 5,2 \mathrm{~min}$. $\mathrm{NH}_{4} \mathrm{~F}: \mathrm{HNO}_{3}=1: 30,1 \mathrm{~min}$. $1070^{\circ} \mathrm{C}, 3 \mathrm{hr} ., 2 \%$ TCA in $\mathrm{O}_{2}$ Rear boron windows $(30 \times 30-\mu \mathrm{m})$

$\mathrm{BBr}_{3}$ source $900^{\circ} \mathrm{C}$ then $3 \mathrm{hr}$. at $1080^{\circ} \mathrm{C}$ in $5 \% \mathrm{O}_{2}$ in $\mathrm{N}_{2}$

$\mathrm{HF}: \mathrm{H}_{2} \mathrm{O}=1: 20, \sim 6 \mathrm{~min}$.

$1070^{\circ} \mathrm{C}, 3 \mathrm{hr}$., $2 \%$ TCA in $\mathrm{O}_{2}$

Fat finger pattern

Phosphorus solid source, $910^{\circ} \mathrm{C}, 30 \mathrm{~min}$., $10 \Omega / \square$

$\mathrm{HF}: \mathrm{H}_{2} \mathrm{O}=1: 20,1 \mathrm{~min}$.

$1050^{\circ} \mathrm{C}, 1 \mathrm{hr} ., 2 \% \mathrm{TCA}$ in $\mathrm{O}_{2}$

Emitter junction definition

$820^{\circ} \mathrm{C}, 20 \mathrm{~min} ., 300 \Omega / \square$

$\mathrm{HF}: \mathrm{H}_{2} \mathrm{O}=1: 20,3 \mathrm{~min}$.

$1000^{\circ} \mathrm{C}, 95 \mathrm{~min}$., $2 \% \mathrm{TCA}$ in $\mathrm{O}_{2}$.

$15 \mathrm{~min}$. annealing in $\mathrm{Ar}$

Metal finger pattern, rear contact holes

Busbar area without HF etching

Ti/Pd:600/600 $\AA$, lift off

Al:2- $\mu \mathrm{m}$

Electrolytic, 8- $\mu \mathrm{m}$

$400^{\circ} \mathrm{C}, 30$ min., $4 \% \mathrm{H}_{2}$ in $\mathrm{Ar}$ 
Empirical optimization of this device structure during the present project produced some excellent cells as shown in Table 3.2. These cells perform exceptionally well at low concentration levels, but their performance deteriorates rapidly above about 30 suns' concentration. These results were measured before application of prismatic covers. Considering that these results are within $7 \%$ of the best previously demonstrated (Table 2.3) and that prismatic covers for cells with the present contact pattern generally give at least $10 \%$ improvement in performance, these cells are close to the best fabricated to date with this sequence. However, the cells are still a long way from demonstrating the full potential of the PERL approach.

Table 3.2: Efficiency of cell CC13-2L under concentrated sunlight, without prismatic covers applied. One-sun responsivity is 0.372 AW (Direct beam AM1.5 spectrum, $25^{\circ} \mathrm{C}$, cell area $1.583-\mathrm{cm}^{2}$, measurements courtesy of Sandia National Laboratories).

\begin{tabular}{|l|c|c|c|}
\hline Suns & $V_{\text {oc }}(\mathrm{mV})$ & FF (\%) & Effic. (\%) \\
\hline 1 & 681 & 81.9 & 20.7 \\
\hline 12 & 745 & 83.7 & 23.2 \\
\hline 19 & 758 & 81.6 & 23.0 \\
\hline 34 & 771 & 77.9 & 22.3 \\
\hline 57 & 782 & 72.7 & 21.1 \\
\hline 97 & 792 & 64.7 & 19.0 \\
\hline 136 & 798 & 57.9 & 17.2 \\
\hline 203 & 805 & 49.1 & 14.7 \\
\hline
\end{tabular}

Accordingly, empirical optimization was abandoned in favor of more analytically orientated work aimed at identifying the factors responsible for this less-than-ideal performance, toward the later stages of the present reporting period. Improved techniques were identified for accurately determining cell resistance and for separately determining contact and bulk resistance.

\subsection{Current-Voltage Analysis}

During the course of the present project, an improved understanding of the operation of PERL cells was gained by analysis of the dark current-voltage curves. These 
curves can typically be divided into three segments [1]. There is a low-voltage segment at voltages less than $0.4 \mathrm{~V}$ with unity ideality factor, followed by an intermediate region with high ideality factor (greater than about 1.4) and finally, a high-voltage regime at voltages greater than about $0.6 \mathrm{~V}$ with ideality factor again approaching unity.

These characteristics are explained by an injection level dependence of the recombination velocity along the non-contacted regions of the rear surface. Due to a large asymmetry between electron and hole capture cross sections, the rate of recombination along this surface depends primarily upon the concentration of holes near the rear region. Since this concentration does not increase greatly with increased voltage across the cell, the corresponding recombination rate does not change very much either. However, rear surface recombination velocity is referenced to the minority carrier electron concentration near the rear surface. This concentration does increase rapidly with increased voltage across the cell. The net result is an effective rear surface recombination velocity, which decreases very rapidly with increasing cell voltage. At about $0.4 \mathrm{~V}$, the cell switches from a mode of operation corresponding effectively to infinite rear recombination to one with a finite, but variable, rear surface recombination velocity. Above $0.6 \mathrm{~V}$, a new recombination mechanism associated with the front surface emitter becomes more important, overriding these rear surface effects.

For concentrator cells, the high-voltage regions are of most interest. At such high voltages, Figure 3.2 shows three types of current-voltage curve measured during this work, in this case for a $4-\mathrm{cm}^{2}$ cell with a one-sun mask pattern. One curve is the dark current-voltage (I-V) curve as discussed in earlier work [1]. A second curve a plot of open-circuit voltage as a function of cell short-circuit current $\left(\mathrm{V}_{\mathrm{OC}}{ }^{-} \mathrm{I}_{\mathrm{sc}}\right)$. The third curve is the measured current-voltage (I-V) curve of the cell under illumination shifted up into the first quadrant by adding the short-circuit current density to each measured current point.

Comparing the dark $\mathrm{I}-\mathrm{V}$ with the $\mathrm{V}_{\mathrm{oc}}{ }^{-} \mathrm{I}_{\mathrm{sc}}$ curve shows two important effects. At the lower current densities, the two curves coincide, confirming that the rear surface is having little effect upon the cell at these voltage levels. At higher current levels, the two curves deviate due to series resistance effects in the dark I-V curve. 


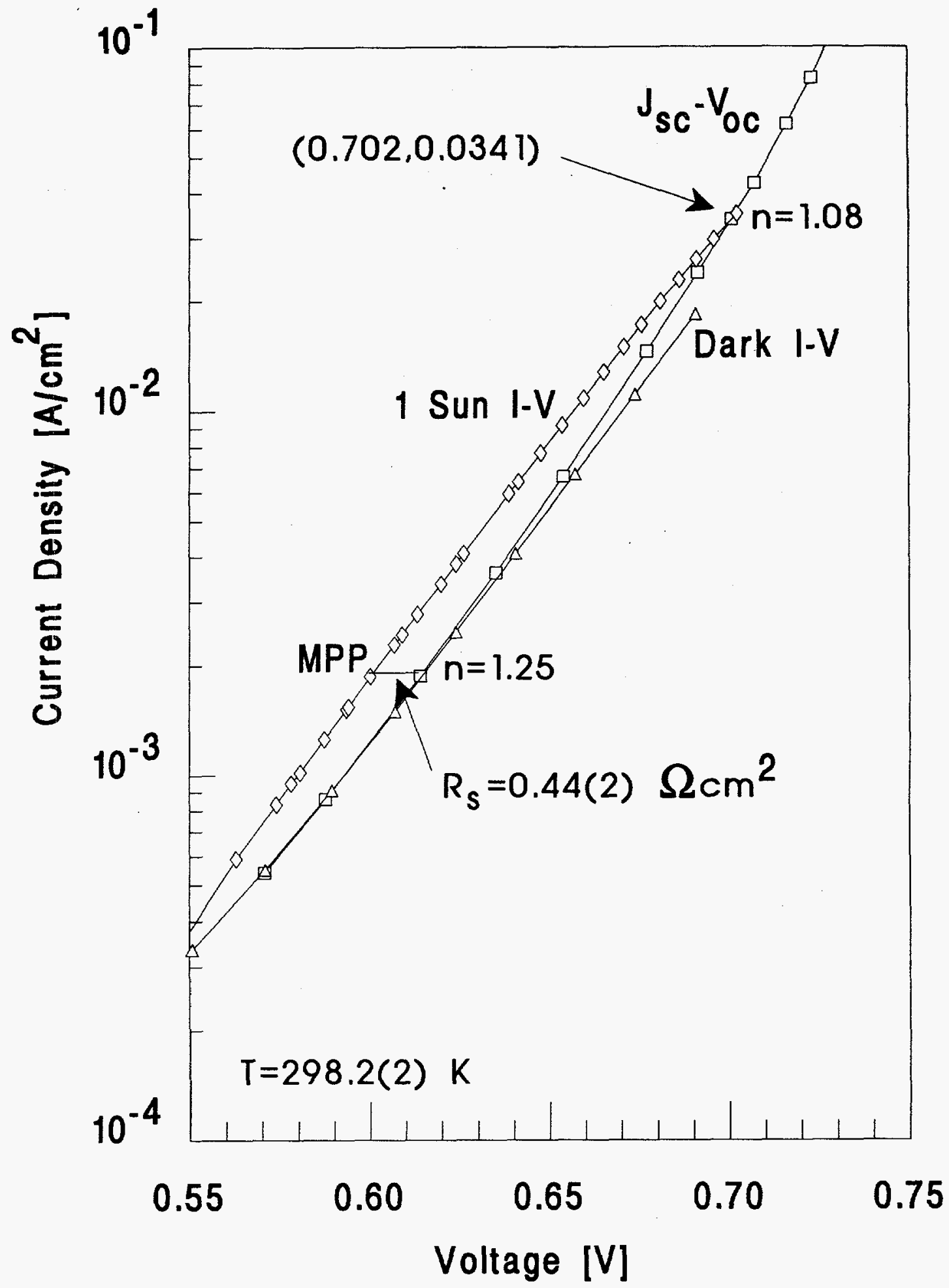

Figure 3.2: Three current-voltage (J-V) curves for planar, one-sun cell Wp2-1L. The dark I-V curve is furthermost right, followed by the $J_{s c}-V_{o c}$ curve, with the illuminated $\mathrm{I}-\mathrm{V}$ curve, shifted to the first quadrant, furthermost left. 
Measurement of the deviation produces a value of series resistance of approximately $0.37 \Omega-\mathrm{cm}^{2}$.

Note, however, that this series resistance may not be relevant to the cell when illuminated. In the dark, current flows are less constrained than in the illuminated case. They would therefore take a lower resistance path between the cell contacts than when the cell is illuminated. Both bulk resistance contributions and contributions from flows along metal fingers would be expected to be smaller in the dark case, although contact resistance values would be similar.

Comparison of the shifted output curve and the $\mathrm{V}_{O c}{ }^{-1} \mathrm{sc}$ curve gives a more accurate measure of the series resistance $\left(R_{S}\right)$ of the illuminated cell. At low currents, these curves should be displaced by a voltage equal to $I_{s c} R_{s}$. By comparing the two curves near the maximum power point, a series resistance value of $0.44(2) \Omega-\mathrm{cm}^{2}$ is deduced.

The good agreement between the dark and illuminated series resistances suggests that contact resistance is a major contributor to the total cell series resistance. Since the contact resistance at the top of the cell would be expected to be similar to that in earlier generations of PESC cells (which have given very low resistance with good performance at high concentration levels), it is deduced that the contact resistance arises from contact between the rear metal (AI) and the heavily doped boron on the rear surface. Boron depletion from surface regions during rear surface oxidation could contribute to these high values.

Further work with PERL cells designed for both one-sun and concentrating applications will address the issue of this contact resistance and is expected to greatly improve performance at high concentration levels.

\subsection{Ultraviolet Stability}

Due to stability problems reported with high performance Stanford rear contact cells, the ultraviolet stability of UNSW cells of similar performance level became of obvious interest. The Stanford cell provides an almost perfect test structure for testing of surface stability. Not surprisingly, in view of reduced surface sensitivity, ultraviolet 
stability testing has revealed that UNSW are far more stable. In fact, it is concluded that other system components such as lenses are likely to be of more concern than these cells.

Ultraviolet stability testing was conducted at UNSW using a mercury lamp, as well as UVA and UVB lamps for testing, supplemented by real time outdoor tests. This work was complemented by measurements at Sandia Laboratories using a Xenon arc simulator. This simulator produced a UV spectrum similar to that in the solar spectrum, but of much higher intensity [6]. A large amount of data was generated during this testing, supporting the general conclusions outlined.

The test structures chosen for this work were cells with one-sun metallization patterns. In UNSW processing, two such cells are normally fabricated, side by side, on a $5-\mathrm{cm}$ diameter wafer. Both cells invariably have nearly identical characteristics. In this work, cells were not scribed from these wafers but were tested intact. One cell was shaded from the UV source and acted as a control.

Near the end of this testing program, it was realized that this procedure was unduly conservative. Most of the changes in cell output observed were due to a reduction in current output. This was traced to a reduction in the amount of current collected from the periphery of the cell. Since these regions are not diffused, they would be expected to be quite sensitive to UV-induced changes in surface states and oxide charge or to the deposition of negative charges along the top of the cell during the UV testing.

This is an important result in that it suggests that careful attention has to be paid to edge junction isolation in the design of a cell for a severe UV environment. However, the effect does complicate the interpretation of the testing done during the program. The results upon cells designed with appropriate edge junction isolation would be less ultraviolet sensitive than those to be described below.

The first test at UNSW established that high-energy ultraviolet light could damage UNSW cells. This was a harsh test involving exposure for 600 hours to $254 \mathrm{~nm}$ light from a mercury lamp. Using the acceleration factor deduced by Stanford University in similar testing [6], this corresponded to over 1,000 years damage at one-sun or 50 
years damage at 200 suns' concentration.

This severe exposure reduced the open-circuit voltage of the exposed cell from 696 $\mathrm{mV}$ to $615 \mathrm{mV}$. Short-circuit current dropped $20 \%$, fill factor dropped by $2 \%$ with overall power output reduced by $27 \%$. Heating for 30 minutes at circa $400^{\circ} \mathrm{C}$ in a $4 \%$ $\mathrm{H}_{2} / \mathrm{Ar}$ mixture restored performance to within $1 \%$ of its original level.

Further testing at UNSW under UVB and UVC lamps supported the fact that high-energy UV particles were particularly effective in creating this damage. However, testing of bare cells may be unduly conservative. Figure 3.3 shows the photon content of global AM1.5 light compared to the transmission of a typical acrylic lens favored for concentrator systems [4]. The acrylic lens has a cut off of about 375 $\mathrm{nm}$, undoubtedly due to the presence of UV stabilizers in the acrylic to prevent deterioration of the lens itself. These stabilizers would remove the most damaging photons from the incident sunlight.

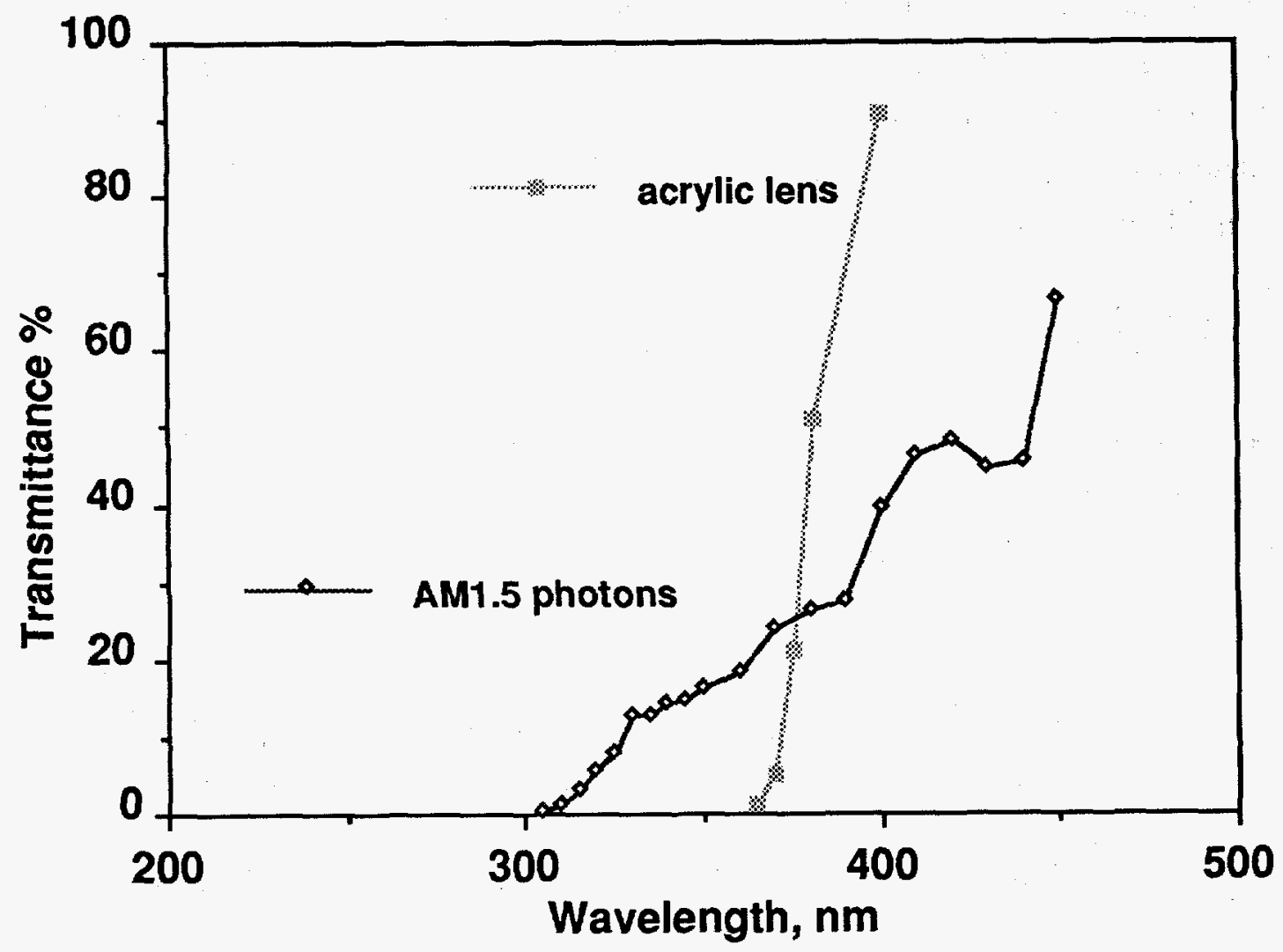

Figure 3.3: Transmissivity of acrylic lens compared to photons in sunlight. 
Given the sensitivity to edge effects previously mentioned and the UV absorbing properties of other system components, it was concluded that the most sensible way of testing for ultraviolet stability would be as part of an overall concentrating system. The initial testing to date has suggested that the cell would be sufficiently stable that degradation of other components such as lenses may be just as important in such configurations.

Testing at Sandia National Laboratories provides additional information on the ultraviolet ruggedness of various cell technologies [7]. There was no change in output observed for either the PESC or PERL cells to within measurement accuracy for the duration of the exposure, although other cell technologies did show some problems (the PESC cells were fabricated by Applied Solar Energy Corporation after transfer of UNSW technology).

Ultraviolet stability is definitely an important issue for silicon cells, particularly as output voltages continue to increase. However, some caution is advised when developing acceptable standards for such cells in case these become too conservative, given the well known ultraviolet sensitivity of other system components such as lenses and encapsulants.

\subsection{Summary}

Although empirical optimization of PERL cells produced very creditable efficiencies early in the project, problems with rapidly deteriorating performance at high concentration levels persisted.

Subsequent work concentrated on identifying the source of the resistance responsible for this deterioration of performance. Analysis of illuminated and dark current-voltage curves has resulted in the identification of the source as being contact resistance between rear aluminum and the boron diffused contact areas. Addressing this problem is expected to result in substantial improvements in PERL concentrator cell performance in the medium term.

Although extensive ultraviolet stability testing was conducted during this work, this 
work was marred to some extent by the use of an inappropriate test structure. This structure, although giving acceptable results, produces an over-estimate of the ultraviolet sensitivity of PERL cells. However, results that were obtained suggest that ultraviolet sensitivity is not an immediate issue for PERL cells. It is recommended that further testing be conducted as part of the overall life testing of assembled systems, due to the ultraviolet absorbing properties of lenses and the dependence upon the precise nature of edge junction isolation used in the cell design. 


\section{SECTION 4}

\section{N-TYPE PASSIVATED EMITTER CELLS}

\subsection{Introduction}

In a related project [1], excellent progress was made in development of passivated emitter cells upon n-type substrates. These cells were thought to be particularly promising for concentrator applications due to the primarily diffusive collection of carriers and consequently lower bulk series resistance. This section summarizes recent developments with passivated emitter cells upon n-type substrates, the application of this technique to n-type concentrator cells and the results of testing such concentrator cells at high concentration levels.

\subsection{One Sun Results}

A summary of results obtained with passivated emitter structures upon n-type substrates is shown in Table 4.1.

Table 4.1: Results for n-type substrates for a variety of front and rear junction PERL and PERT cells (4-cm ${ }^{2}$ ) of differing thickness as measured at Sandia National Laboratories (AM1.5G, $100 \mathrm{~mW} / \mathrm{cm}^{2}, 25^{\circ} \mathrm{C}$ ).

\begin{tabular}{|c|c|c|c|c|c|c|}
\hline Cell & Structure & $\begin{array}{c}W \\
(\mathrm{~mm})\end{array}$ & $\begin{array}{l}V_{o c} \\
(\mathrm{mV})\end{array}$ & $\begin{array}{c}J_{\mathrm{sc}} \\
\left(\mathrm{mA} / \mathrm{cm}^{2}\right)\end{array}$ & $\begin{array}{l}\mathrm{FF} \\
(\%) \\
\end{array}$ & $\begin{array}{l}\text { Effic. } \\
(\%)\end{array}$ \\
\hline$x-1-158 R$ & $\begin{array}{c}\mathrm{p}^{+} \mathrm{nn}^{+} \mathrm{PERL} \\
\text { (planar) }\end{array}$ & 280 & 671 & 34.0 & 81.3 & 18.6 \\
\hline$X-1-201 R$ & $p+n n+P E R L$ & 280 & 658 & 39.8 & 81.6 & 21.3 \\
\hline$x-1-215$ & $n+n p+P E R T$ & 280 & 691 & 38.3 & 81.1 & 21.4 \\
\hline$X-1-274 R$ & $n+n p+P E R L$ & 275 & 693 & 37.2 & 79.0 & 20.4 \\
\hline $\mathrm{X}-1-279 R$ & $n+n p+P E R L$ & 230 & 691 & 37.4 & 78.6 & 20.3 \\
\hline$x-1-280 R$ & $n+n p+P E R L$ & 160 & 696 & 37.8 & 80.5 & 21.2 \\
\hline$x-1-305$ & $n+n p+P E R T$ & 280 & 692 & 39.2 & 80.4 & 21.8 \\
\hline$x-1-310$ & $n+n p+P E R T$ & 150 & 694 & 39.3 & 80.3 & 21.9 \\
\hline
\end{tabular}


Applying the standard PERL type structure to n-type substrates, with doping polarities all reversed, produced good results upon planar substrates. When applied to cells with textured top surfaces, the open-circuit voltages demonstrated were deficient as shown by the second entry in Table 4.1 (Cell X-1-201R). This reduced voltage is due to the large saturation current density of the boron diffused top surface region in this cell, enhanced by the increased surface area resulting from surface texturing. The overall efficiency of $21.3 \%$, however, is quite creditable given that the highest efficiency measured at Sandia upon n-type substrates prior to this work was $21.6 \%$ [1].

In order to increase voltage output, various rear junction structures were examined with the boron diffusion on the planar rear surface: Figure 4.1 shows the structure of an n-type, rear junction PERT cell (passivated emitter, rear totally diffused) fabricated in this way. Rear junction PERL cells have a similar structure but the rear boron diffusion is localized to contact areas. As shown in Table 4.1, excellent results were obtained in this way particularly for PERT cells. These cells have demonstrated the highest efficiencies measured at Sandia for any cells upon n-type substrates.

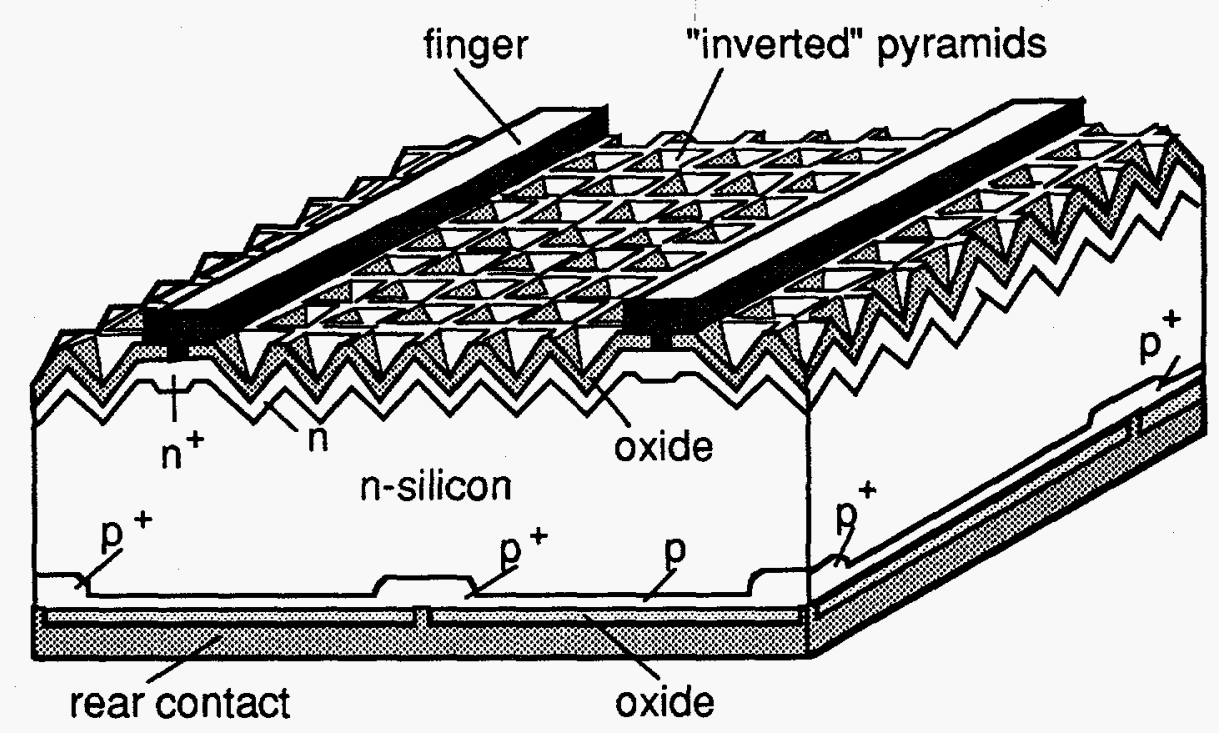

Figure 4.1: Rear Junction PERT cell 
One interesting point incorrectly interpreted in an earlier discussion of these results [1] is the difference in current output between rear junction PERL and PERT cells. An examination of the spectral response of these cells shows that the difference in current is due to lower carrier collection at short wavelengths from PERL-type cells. The explanation for this is not due to a difference in diffusion lengths, as originally proposed [1]. Rather it is due to the fact that carriers generated near the top surface have to diffuse to a more confined region of the rear surface in the PERL structure. This increases the surface concentration of minority carriers required to drive this process and correspondingly increases the proportion of minority carriers lost through both top surface and bulk recombination. This process increases such recombination by a factor of about three compared to the PERT structure. Similar carrier confinement mechanisms will also prevail in rear point contact cells such as those developed at Stanford University, highlighting the exceptional quality of bulk and surface passivation required to produce good cells with this approach, compared to the more rugged PERL cells of Section 2.

\subsection{N-Type Concentrator Cells}

Given the excellent performance of the rear junction PERT cells, the prospects for fabricating good $n$-type concentrator cells with this approach were rated very favorably. Accordingly, it was with some enthusiasm that batches of concentrator cells were fabricated using the sequence of Table 4.2.

Given this enthusiasm, the results were quite disappointing. Cells used the same picture frame busbar design as for the PERL cells of the previous section and described in more detail elsewhere [2]. Open-circuit voltages were lower than for one-sun cell designs by about $20 \mathrm{mV}$. Cell performance at one-sun concentration was quite creditable. However, the measurement of the cells under concentration produced several measurement challenges. The lifetimes in the cells were so high that severe problems with sweep rate dependence of the measured performance arose. Additionally, there was a pronounced sublinearity in the response of the current output of the devices. Accordingly, there are much larger measurement uncertainties with these cells than in normal Sandia measurements. Tables 4.3 and 4.4 show the measured results for a cell of $150-\mu \mathrm{m}$ and $280-\mu \mathrm{m}$ thickness respectively. At the relatively low concentration levels, sweep rate dependencies 
Table 4.2: Processing sequence for rear junction, n-type PERT concentrator cells.

STEP

1. Wafer Selection

2. Thinning Wafer

3. Chemical Polishing

4. Oxide Growth

5. Oxide Patterning

6. Surface Etching

7. Rounding

8. Front Oxide Removal

9. Rounding

10. Rear Oxide Removal

11. Oxide Growth

12. Oxide Patterning

13. Rear Heavy Boron Diffusion

14. Deglaze

15. Oxide Growth

16. Oxide Patterning

17. Rear Emitter Diffusion

18. Deglaze

19. Oxide Growth

20. Oxide Patterning

21. Front Heavy Phosphorus Diffusion

22. Deglaze

23. Oxide Growth

24. Oxide Patterning

25. Front Active Area Diffusion

26. Deglaze

27. Passivation Oxide Growth

28. Oxide Patterning

29. Contact Metal Evaporation and Lift Off

30. Ag Plating

31. Sinter

\section{PROCESS}

$1 \Omega$-cm, (100), FZ, n-type Si, 280-mm thick, $\Phi=50.8-\mathrm{mm}$, both sides polished.

$\mathrm{KOH}: \mathrm{H}_{2} \mathrm{O}=50 \mathrm{~g} / 100 \mathrm{ml}, 85^{\circ} \mathrm{C}, 150 \sim 160-\mu \mathrm{m}$ thick.

$\mathrm{HNO}_{3}: \mathrm{HF}: \mathrm{CH}_{3} \mathrm{COOH}=15: 2: 5$ by volume. $1050^{\circ} \mathrm{C}, 1.5 \mathrm{hr}$., $2 \% \mathrm{TCA}$ in $\mathrm{O}_{2}$.

Inverted pyramids on the front active area.

$\mathrm{KOH}: \mathrm{H}_{2} \mathrm{O}=8 \mathrm{~g} / 100 \mathrm{ml}, 70^{\circ} \mathrm{C}$.

$\mathrm{HNO}_{3}: \mathrm{NH}_{4} \mathrm{~F}=30: 1,1 \mathrm{~min}$.

$\mathrm{HF}: \mathrm{H}_{2} \mathrm{O}=1: 5$.

$\mathrm{HNO}_{3}: \mathrm{NH}_{4} \mathrm{~F}=30: 1,1 \mathrm{~min}$.

$\mathrm{HF}: \mathrm{H}_{2} \mathrm{O}=1: 5$

$1050^{\circ} \mathrm{C}, 4.5 \mathrm{hr}$., $2 \% \mathrm{TCA}$ in $\mathrm{O}_{2}$.

8- $\mu \mathrm{m}$ width finger pattern, rear active area.

Boron liquid source $\left(\mathrm{BBr}_{3}\right)$ predeposition:

$900^{\circ} \mathrm{C}, \mathrm{N}_{2}$ and $\mathrm{O}_{2}$.

Drive in: $1080^{\circ} \mathrm{C}, \mathrm{N}_{2}$ and $\mathrm{O}_{2}$

$10 \sim 20 \Omega /$ square.

$\mathrm{HF}: \mathrm{H}_{2} \mathrm{O}=1: 5$.

$1050^{\circ} \mathrm{C}, 1 \mathrm{hr}$., $2 \%$ TCA in $\mathrm{O}_{2}$.

Rear active area.

Boron liquid source $\left(\mathrm{BBr}_{3}\right)$ predeposition: $930^{\circ} \mathrm{C}, 35 \mathrm{~min}$., $\mathrm{N}_{2}$ and $\mathrm{O}_{2}, 80 \Omega$ /square.

$\mathrm{HF}: \mathrm{H} 2 \mathrm{O}=1: 5$.

$1050^{\circ} \mathrm{C}, 4.5 \mathrm{hr}$., $2 \%$ TCA in $\mathrm{O}_{2}$.

8- $\mu \mathrm{m}$ width finger pattern, front active area.

Phosphorus solid source, $900^{\circ} \mathrm{C}, 35 \mathrm{~min}$. in

$\mathrm{N}_{2}, 20 \Omega$ /square.

$\mathrm{HF}: \mathrm{H}_{2} \mathrm{O}-1: 10$

$1000^{\circ} \mathrm{C}, 30$ min., $2 \%$ TCA in $\mathrm{O}_{2}$.

Front active area.

Phosphorus solid source, $820^{\circ} \mathrm{C}, 20 \mathrm{~min}$. in $\mathrm{N}_{2}, 350 \sim 450 \Omega /$ square.

$\mathrm{HF}: \mathrm{H} 2 \mathrm{O}=1: 10$.

$1000^{\circ} \mathrm{C}, 120$ min., $2 \%$ TCA in $\mathrm{O}_{2}, 15 \mathrm{~min}$. annealing in Ar.

Front and rear metallization.

Top: Ti/Pd (650Å/650Å)

Rear: Al (1.4- $\mu \mathrm{m})$.

Electrolytic, $9-\mu \mathrm{m}$.

$400^{\circ} \mathrm{C}, 30 \mathrm{~min}$. in forming gas. 
were so severe that the fill factor value was estimated at $80 \%$, probably quite a conservative estimate given the one-sun values.

Table 4.3: Efficiency of cell X-1-3L ( 150- $\mu \mathrm{m}$ thick) under concentrated sunlight, without prismatic covers applied. One-sun responsivity is $0.353 \mathrm{AWW}$ (Direct beam AM1.5 spectrum, $25^{\circ} \mathrm{C}$, cell area $1.576-\mathrm{cm}^{2}$, measurements courtesy of Sandia National Laboratories).

\begin{tabular}{|l|c|c|c|c|}
\hline Suns & $V_{\text {oc }}(\mathrm{mV})$ & $I_{\text {SC }}$ Sublinearity & FF (\%) & Effic. (\%) \\
\hline 1 & 673 & 1.000 & 81.8 & 19.4 \\
20 & 758 & 0.937 & $80.0^{*}$ & $19.9^{\star}$ \\
50 & 778 & 0.908 & $80.0^{*}$ & $19.9^{\star}$ \\
100 & 793 & 0.885 & 76.0 & 18.8 \\
200 & 807 & 0.854 & 68.1 & 16.6 \\
\hline
\end{tabular}

* conservatively estimated

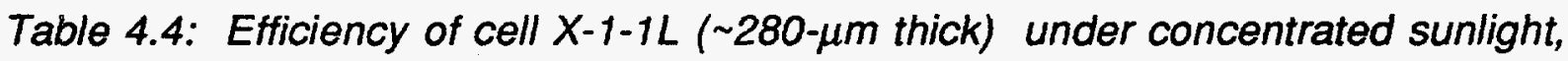
without prismatic covers applied. One-sun responsivity is $0.345 \mathrm{AWW}$ (Direct beam AM1.5 spectrum, $25^{\circ} \mathrm{C}$, cell area $1.576-\mathrm{cm}^{2}$, measurements courtesy of Sandia National Laboratories).

\begin{tabular}{|l|c|c|c|c|}
\hline Suns & Voc (mV) & $I_{\text {SC Sublinearity }}$ & FF (\%) & Effic. (\%) \\
\hline 1 & 669 & 1.000 & 81.2 & 18.7 \\
20 & 755 & 0.917 & $80.0^{*}$ & $19.1^{*}$ \\
50 & 774 & 0.880 & $80.0^{*}$ & $18.8^{*}$ \\
100 & 789 & 0.836 & 78.6 & 17.8 \\
200 & 801 & 0.769 & 72.2 & 15.3 \\
\hline
\end{tabular}

* conservatively estimated

Performance at low concentration levels is quite good. However, both series resistance effects and a sublinearity in the cell responsivity causes a rapid deterioration in performance at the higher concentration levels. The contact resistance between the rear doped boron and rear aluminum metal contact, as identified in the previous section, is probably the cause of this series resistance. The 
sublinearity is due to emitter recombination as previously analyzed [8].

Even upon short-circuit, the minority carrier density builds up toward the top surface to drive the short-circuit current through the cell. This causes the minority carrier concentration in the emitter of the cell to also increase, causing finite emitter recombination at short-circuit, reducing the short-circuit current of the cell.

An analysis of this effect for a p-type cell under high-injection conditions will transfer to the present cell structure when also in high injection [8]. Under low-injection conditions, the loss mechanism will be present but will not produce a sublinear response (a very similar effect accounts for the difference in responsivity between rear junction PERL and PERT cells, as previously described).

These disappointing results led to the conclusion that considerably more effort is required to successfully fabricate a rear junction cell of this type than had been anticipated. Accordingly, the best prospects for fabricating a cell upon n-type substrates is believed to be with the normal front junction PERL structure upon low resistivity substrates. This will give relatively low-voltage output but good responsivity and eliminate the sublinearities observed for the present cells.

\subsection{Summary}

Excellent progress was made during the present reporting period with cells upon ntype substrates. One-sun efficiencies up to $21.9 \%$ were independently confirmed at Sandia during this work, the highest ever measured at Sandia for cells upon n-type substrates. Due to high saturation current contributions of boron diffused regions, best one-sun results were obtained with rear junction PERT cell structures.

Disappointing results were obtained when this structure was used to fabricate concentrator cells. The structure did not eliminate all the resistance problems of the p-type PERL cells as had been thought possible. This supports the identification of this resistance as being due to the contact between the rear metal and heavily boron diffused regions. Additionally, cells demonstrated a pronounced sublinearity in responsivity as, in retrospect, would have been predicted by an earlier analysis by our group of $p$-type cells in high-injection conditions. 
At the present stage of development, the most promising structure for fabricating high-efficiency n-type cells with UNSW technology is to use a normal front junction PERL structure upon low-resistivity n-type substrates. It is difficult to see that this structure would give any substantial advantage over a similar structure upon p-type substrates. Open-circuit voltage would be lower near one-sun conditions. Dember voltage enhancement of this voltage might help reduce this deficiency under concentration. There is, however, a penalty to be paid for Dember voltage enhancement in the form of increased effective resistance of the cell [9]. 


\section{SECTION 5}

\section{TECHNOLOGY TRANSFER ACTIVITIES}

\subsection{Introduction}

One objective of the present project was to support the transfer of technology to a commercial environment in the U.S. During the present project, technology was very successfully transferred to Applied Solar Energy Corporation. This company has reported greatly improved concentrator cell performance as a result of this transfer, and is also offering an improved space cell product. Technology transfer to Solarex Corporation was also achieved during the present reporting period.

\subsection{PESC Sequence}

The processing sequence for producing the PESC cell (passivated emitter solar cell) of Figure 5.1 was successfully transferred to Applied Solar Energy Corporation (ASEC) during this project.

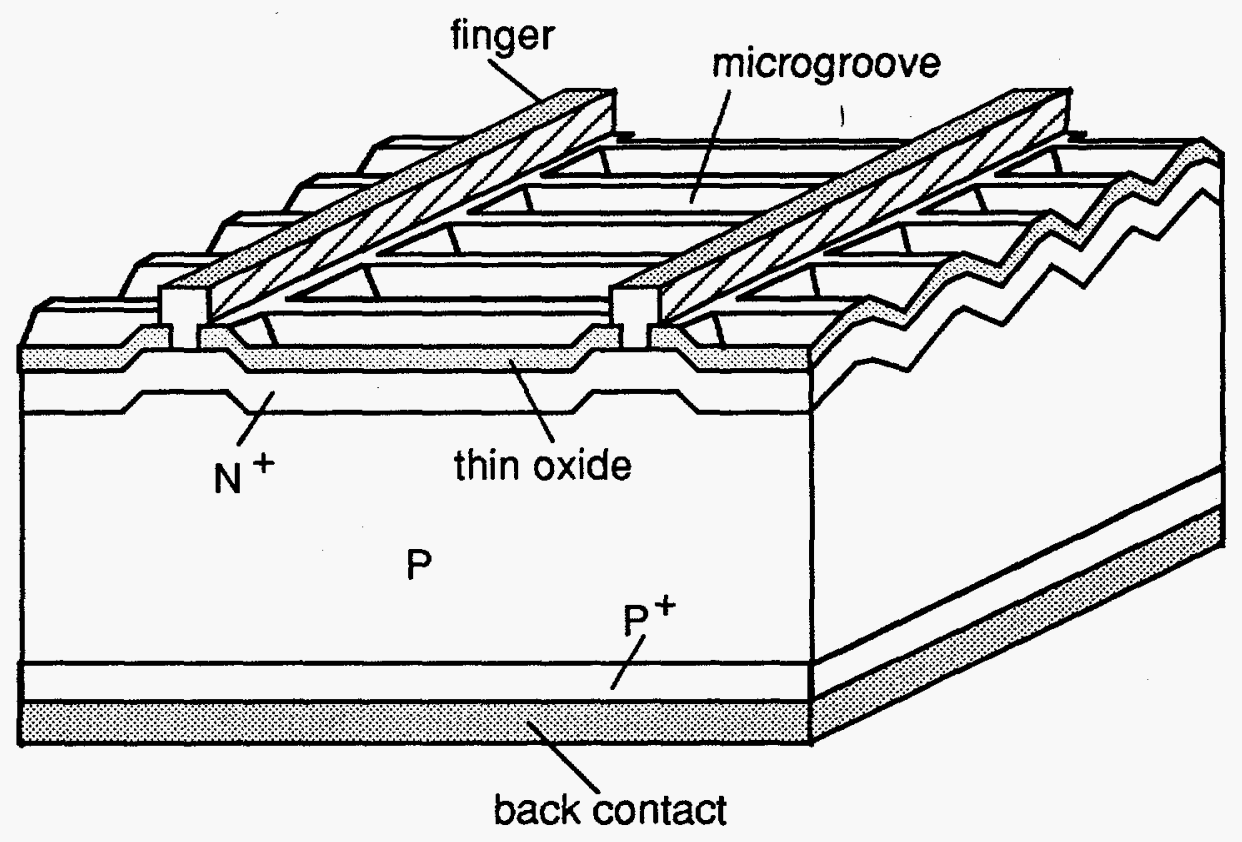

Figure 5.1: PESC cell [2]. 
The results of this collaboration have been reported in some detail $[10,11]$. ASEC reported upon the results of both the 4-mask and 5-mask sequence involving samples with fingerwidths ranging from 2-20 $\mu \mathrm{m}$ using substrates of 0.15 and 0.2 $\Omega$-cm resistivity. Although the resulting cells were designed for use with prismatic covers, efficiencies up to $21.8 \%$ have been obtained in this work without the application of covers. These cells are very clearly superior to any concentrator cells previously made by ASEC, one of the more experienced commercial manufacturers of concentrator cells. Mask sets have also been developed for cells designed for high efficiency without the use of prismatic covers.

As another result of this activity, ASEC released a data sheet for space cell product showing the availability of space cells of size $2 \times 4-\mathrm{cm}$ to $6 \times 6-\mathrm{cm}$ using such high-efficiency technology (Figure 5.2). Product efficiency is listed as $17 \%$ under the AMO spectrum, compared to $14.8 \%$, the highest efficiency listed for other silicon product offered by the company.

\subsection{Buried Contact Cell Sequence}

Technology for producing the buried contact solar cell of Figure 5.3 has now been licensed to five companies internationally. Of the five licensing signatories, three have been U.S.-owned companies.

Solarex Corporation reported upon its involvement with UNSW to establish buried cell sequence for concentrator solar cells [12]. During the present reporting period, Solarex staff visited UNSW for training in the details of the sequence. UNSW staff visited Solarex buried contact activities and additionally provided advice on the establishment of appropriate processing facilities.

Computer simulations suggest that efficiencies of $21 \%$ at 20 suns' concentration are feasible for buried contact cells approximately $10-\mathrm{cm} \times 5-\mathrm{cm}$ in size. Preliminary results using mechanical grooving have also been reported [12]. 


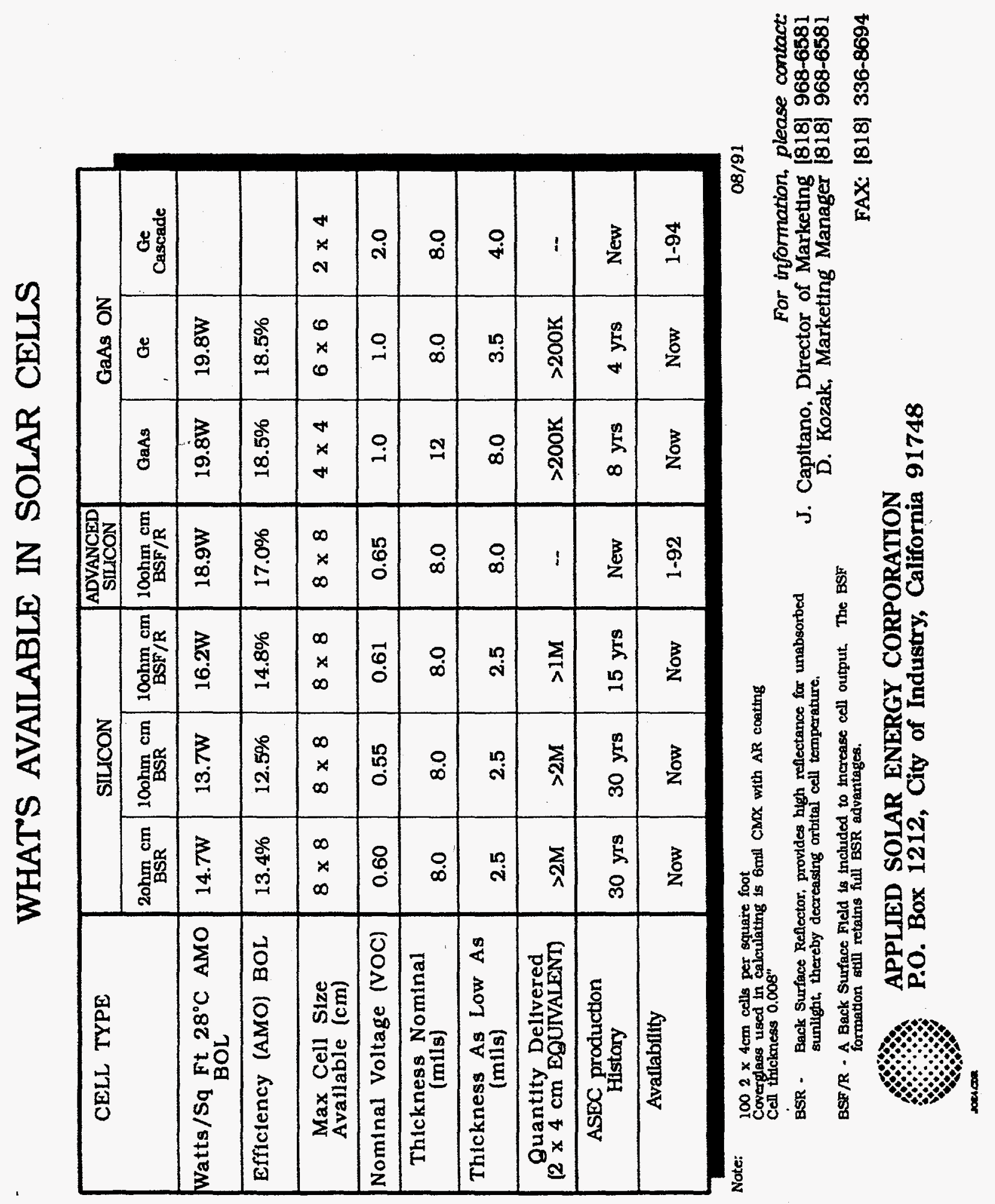

Figure 5.2: ASEC space cell data sheet (September, 1991). 


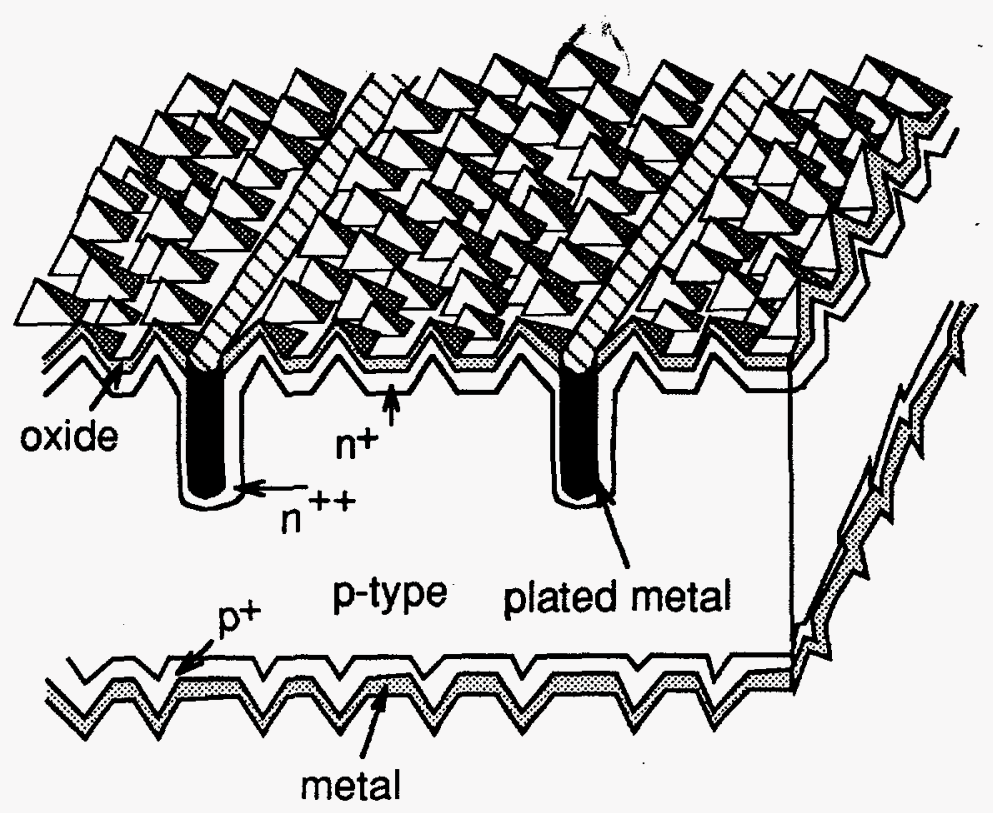

Figure 5.3: UNSW buried contact solar cell.

\subsection{Summary}

Technology transfer to Applied Solar Energy Corporation has been extremely successful. The company is now able to produce commercial concentrator cells of higher efficiency than previously possible. The company is also marketing a new line of silicon space cells of $17 \%$ AMO efficiency compared to the value of $14.8 \%$ which was the highest listed by the company with other silicon technology.

Solarex Corporation also reported upon preliminary results of a program aimed at establishing UNSW buried contact cell technology. This effort is expected to produce similarly impressive outcomes in the near future. 


\section{SECTION 6}

\section{REFERENCES}

1. M.A. Green, S.R. Wenham, F. Zhang, J. Zhao and A. Wang, Concentrator Silicon Cell Research, SAND91-7016, Sandia National Laboratories, April 1992.

2. M.A. Green, J. Zhao, A. Wang and A.W. Blakers, Silicon Solar Cell Development, SAND89-7043, Sandia National Laboratories, May 1990.

3. D.L. King and D.E. Arvizu, "Crystalline Cell Research: Today and Tomorrow," Conf. Record, 19th IEEE Photovoltaic Specialists Conference, New Orleans, May 1987, pp. 45-48.

4. H.F. MacMillan, H.C. Hamaker, N.R. Kaminar, M.S. Kuryla, M.J. Riston, D.D. Liu, G.F. Virshup and J.M. Gee, "28\% Efficient GaAs Concentrator SolarCells," Conf. Record, 20th IEEE Photovoltaic Specialists Conference, Las Vegas, September 1988, p. 462.

5. J.P. Benner, "Cost Reduction Technology for High-Efficiency Photovoltaics: Research Issues and Progress," Conf. Record, 22nd IEEE Photovoltaic Specialists Conference, Las Vegas, October 1991, pp. 7-11.

6. P.E. Greunbaum, R.A. Sinton and R.M. Swanson, "Stability Problems in Point Contact Solar Cells," Conf. Record, 20th IEEE Photovoltaic Specialists Conference, Las Vegas, September, 1988, p. 423.

7. D.S. Ruby and W.K. Schubert, "The Effects of Concentrated Ultraviolet Light on High-Efficiency Silicon Solar Cells," Conf. Record, 22nd IEEE Photovoltaic Specialists Conference, Las Vegas, October 1992, p. 111.

8. M.A. Green, Jianhua Zhao and D.L. King, "Sublinear Current Response in High Efficiency, High Resistivity Silicon Solar Cells: Theory and Experiment," Appl. Phys. Lett., Vol. 52, pp. 1361-1363, 1988. 
9. M.A. Green, A.W. Blakers, J. Zhao, A. Wang, A.M. Milne, X. Dai and C.M. Chong, High Efficiency Silicon Concentrator Solar Cell Research, SAND897041, Sandia National Laboratories, December 1989.

10. S. Kemthong, S. Cabaniss, J. Zhao and A. Wang, "Low Cost Silicon Solar Cells with High Efficiency at High Concentrations," Conf. Record, 22nd IEEE Photovoltaic Specialists Conference, Las Vegas, October 1991, pp. 268-272.

11. Applied Solar Energy Corporation, Development of Concentrator Cells: Technical Status Report - Phase 1 Report, SAND92-7006, Sandia National Laboratories, June 1992.

12. J.H. Wohlgemuth and S. Narayanan, "Buried Contact Concentrator Solar Cells," Conf. Record, 22nd IEEE Photovoltaic Specialists Conference, Las Vegas, October 1991, pp. 273-277. 
Distribution:

Alpha Solarco

Attn: Anco Blazev

6507 South Hardy Drive

Tempe, AZ 85283

Amonix, Inc. (2)

Attn: Sewang Yoon

Vahan Garboushian

3545 West Lomita Boulevard

Unit A

Torrance, CA 90505

Applied Solar Energy Corp. (2)

Attn: Frank Ho Henry Yoo

15251 East Don Julian Road

City of Industry, CA 91746

Arizona State University (3)

College of Engineering and

Applied Science

Attn: Robert Hammond

Charles Backus

Dieter Schroder

Tempe, AZ 85287-5806

AstroPower

Attn: Allen Barnett

Solar Park

Newark, DE 19716-2000

Black and Veatch

Attn: Kevin Kerschen

Post office Box 8405

Kansas City, MO 64114

Boeing Aerospace

Attn: Dr. John W. Yerkes

High Technology Center

Post Office Box 3999, MS 7J-71

Seattle, WA 98124-2499

Crystal Systems

Attn: Fred Schmid

27 Congress Street

Salem, MA 01970

ENTECH

Attn: Mark O'Neill

P. O. Box 612246

DFW Airport, TX 75261
EPRI (3)

Attn: Frank Dostalek John Bigger Frank Goodman

P. O. Box 10412

Palo Alto, CA 94303

Georgia Institute of

Technology

School of Electrical Engr.

Attn: Professor Ajeet Rohatgi

Atlanta, GA 30331

James Associates

Attn: Larry James

7329 Meadow Court

Boulder, CO 80301

Kopin

Attn: Ron Gale

695 Myles Standish Blvd.

Taunton, MA 02780

Massachusetts Institute of Technology

Attn: Lionel c. Kimerling

77 Massachusetts Avenue

Room 13-5094

Cambridge, MA 02139

Midway Labs

Attn: Paul Collard

2255 East 75th Street

Chicago, IL 60649

Mobil Solar Energy Corp.

Attn: Juris Kalejs

Four Suburban Park Drive

Billerica, MA 01821

NASA/Lewis Research Center (2)

Attn: Shiela Bailey

MS 302-1

Dennis Flood

21000 Brookpark Road

Cleveland, $\mathrm{OH} \quad 44135$

NREL (3)

Attn: Bhushan Sopori

Ted Ciszek

John Benner

1617 Cole Boulevard

Golden, CO 80401 
NREL Library

1617 Cole Boulevard

Golden, $C O 80401$

Photonic Power systems, Inc.

Attn: Jan Werthan

550 California Avenue

Palo Alto, CA 94306

Purdue University (2)

Attn: Dick Schwartz Jeff Gray

School of Electrical Engr.

West Lafayette, IN 47907

Siemens solar, Inc.

Attn: Kim Mitchell

Post office Box 6032

Camarillo, CA 93011

Solar Engineering Applications

Attn: Neil Kaminar

305 North Mathilda Avenue

Sunnyvale, CA 94086

Solarex Corporation

Attn: John Wohlgemuth

630 Solarex Court

Frederick, MD 20701

Southern California Edison

Attn: Nick Patapoff

6090 Irwindale Avenue

Irwindale, CA 91702

Spectrolab (2)

Attn: Dmitri Krut

James Albeck

12500 Gladstone Avenue

Sylmar, CA 91342

Spire Corporation

Attn: Michael J. Nowlan

Patriots Park

Bedford, MA 01730

SunPower Corp.

Attn: Richard Swanson

435 Indio Way

Suite 100

Sunnyvale, CA 94086
Texas Instruments

Attn: Jules Levine

Post office Box 655012

Dallas, TX 75265

US Department of Energy

Attn: James Rannels, CE-131

Forrestal Building

1000 Independence Avenue, SW

Washington, DC 20585

University of New South Wales

Attn: Dr. Martin Green

School of Electrical Engr.

Post office Box One

Kensington, NSW 2033

AUSTRALIA

Fraunhofer Institute for solar

Energie Systeme

Attn: Klaus Heidler

oltmannsstrasse 22

D-7800 Freiburg

GERMANY

Instituto de Energia Solar

Ciudad Universitaria, $s / n$

Attn: Antonio Luque

ETSI Telecomunicacion (UPM)

28040 Madrid

SPAIN

6213 T. C. Bickel

6213 P. A. Basore

6213 T. D. Hund

6213 A. B. Maish

6213 J. M. Gee

6213 D. S. Ruby

6213 W. K. Schubert

6218 D. E. Hasti

6219 M. L. Whipple

6219 D. L. King

7141 Technical Library (5)

7151 Tech. Publications (1)

7613-2 Document Processing DOE/OSTI (10)

8523-2 Central Tech. Files (1) 